\title{
Hypertensive pancreatic sphincter
}

Glen A Lehman MD, Stuart Sherman MD

GA Lehman, S Sherman. Hypertensive pancreatic sphincter. Can J Gastroenterol 1998;12(5):333-337. Major papilla pancreatic sphincter dysfunction, a variant of sphincter of Oddi dysfunction, causes pancreatitis or pancreatic-type pain. Endoscopic manometry as performed at endoscopic retrograde cholangiography is the most commonly used method to identify sphincter dysfunction. Noninvasive testing, such as secretin-stimulated ultrasound analysis of duct diameter, is less reliable and of relatively low sensitivity. Two-thirds of patients with sphincter of Oddi dysfunction have elevated pancreatic basal sphincter pressure. Patients with suspected or documented sphincter of Oddi dysfunction may respond to biliary sphincterotomy alone, but warrant evaluation of their pancreatic sphincter if symptoms persist after therapy. Whether such pancreatic and biliary sphincters should be treated at the first treatment session is controversial. Pancreatic sphincterotomy is associated with a complication rate very similar to that of biliary sphincterotomy except that the pancreatitis rate is two- to fourfold higher. Prophylactic pancreatic stenting diminishes such pancreatitis by approximately $50 \%$.

Key Words: Biliary sphincterotomy, Pancreatic sphincterotomy, Papilla pancreatic sphincter hypertension, Sphincter of Oddi dysfunction

M ajor papilla pancreatic sphincter hypertension, a variant of sphincter of Oddi dysfunction, causes pancreatitis or pancreatic-type pain. The minor papilla may also be narrowed and cause obstruction to pancreatic juice flow, but the management of pancreas divisum and minor papilla narrowing will not be covered here.

\section{MANOMETRY OF THE PANCREATIC SPHINCTER - TECHNIQUE AND NORMAL VALUES}

Biliary and pancreatic manometry are performed in essentially the same manner, except that an aspiration-type catheter is essential for pancreatic work (Figure 1) (1). The manometric criteria are the same for diagnosing pancreatic versus biliary sphincter dysfunction. The most accepted criterion is that the basal sphincter pressure is greater than

\section{Hypercontraction du sphincter pancréatique}

RÉSUMÉ : La dysfonction du sphincter pancréatique au niveau de la papille duodénale majeure, qui est une variante de la dysfonction du sphincter d'Oddi, provoque une pancréatite ou une douleur de type pancréatique. La manométrie endoscopique effectuée au moment de la cholangiographie endoscopique rétrograde est la méthode la plus couramment utilisée pour identifier la dysfonction du sphincter. Les épreuves non vulnérantes, comme l'analyse échographique du diamètre du canal pancréatique stimulée par la sécrétine, sont moins fiables et offrent une sensibilité relativement faible. Les deux tiers des patients atteints d'une dysfonction du sphincter d'Oddi présentent déjà une hypercontraction leur sphincter. Les patients qui manifestent une dysfonction du sphincter d'Oddi soupçonnée ou avérée peuvent répondre à la sphinctérotomie seule, mais il faut faire évaluer la fonction de leur sphincter pancréatique si les symptômes persistent après le traitement. On ignore s'il faut ou non traiter d'emblée ces types de sphincters pancréatiques et biliaires. La sphinctérotomie pancréatique est associée à un taux de complication très semblable à celui de la sphinctérotomie biliaire, si ce n'est qu'avec la première, le taux est deux à quatre fois plus élevé. La pose de tuteurs pancréatiques en prophylaxie réduit d'environ $50 \%$ la pancréatite.

Departments of Medicine and Radiology, Indiana University Medical Center, Indianapolis, Indiana, USA

Correspondence and reprints: Dr Glen A Lehman, Indiana University School of Medicine, 550 North Boulevard, Suite 2300, Indianapolis, Indiana, 46202, USA. Telephone 317-274-4821, fax 317-278-0164 


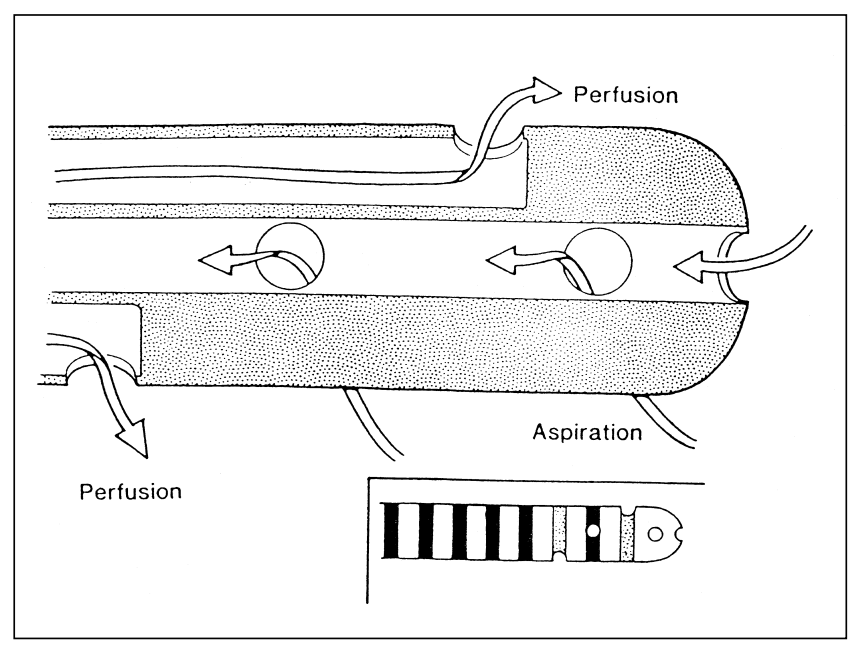

Figure 1) Aspiration catheter

\section{NONMANOMETRIC TESTS OF PANCREATIC SPHINCTER NARROWING}

Indirect tests of pancreatic sphincter disease include secretin-stimulated ultrasound evaluation of the pancreatic duct diameter; pancreatic duct contrast media drainage time at standard ERCP; pancreatic sphincter stenting as a diagnostic trial; and tight sphincter precluding cannulation. The latter two criteria seem very unreliable and are not for clinical use. The first two indirect tests are influenced by the presence of chronic pancreatitis and its associated low exocrine juice flow rate (ie, the duct does not physiologically or pathologically dilate or flush out contrast media if the secretory rate is low). A thorough review of these nonmanometric tests will not be undertaken here, but, in general, most authorities do not accept or widely use these parameters when making therapeutic decisions.

\section{FREQUENCY OF ABNORMAL PANCREATIC BASAL SPHINCTER PRESSURE}

Raddawi et al (4) showed that pancreatic sphincter hypertension was more likely to occur in patients presenting with recurrent pancreatitis versus in those with alkaline phosphatase elevation suggestive of biliary disease. Rolny and colleagues (5) showed that many patients with chronic or recurrent pancreatitis or both had elevated pancreatic sphincter pressure. Vestergaard et al (6) also recently showed that pancreatic sphincter hypertension was common in those with calcific pancreatic disease. In larger studies, Silverman et al (7) and Eversman et al (8) showed that in previously untreated patients undergoing double-duct sphincter of Oddi manometry with measurement of pancreatic basal sphincter pressure and biliary basal sphincter pressure at the same session, the two ducts were in agreement in $70 \%$ of cases (ie, if one duct was normal, both were normal, and if basal pressure was abnormal in one duct, it was abnormal in both) (Table 1). Therefore, pancreatic sphincter hypertension coexists with biliary sphincter hypertension in approximately two-thirds of patients with sphincter of Oddi dysfunction.
TABLE 1

Frequency of abnormal basal sphincter pressure in intact sphincter patients (using biliary criteria)

\begin{tabular}{lrrrrr}
\hline $\begin{array}{l}\text { Biliary } \\
\text { type }\end{array}$ & $\mathbf{n}$ & $\begin{array}{c}\text { Pancreas } \\
\text { alone (\%) }\end{array}$ & $\begin{array}{c}\text { Biliary } \\
\text { alone (\%) }\end{array}$ & Both (\%) & Total \\
\hline III & 214 & $37(17.3)$ & $23(10.7)$ & $67(31.3)$ & $127(59.3)$ \\
II & 123 & $27(22.0)$ & $14(11.4)$ & $39(31.6)$ & $80(65.0)$ \\
I & 23 & $4(17.4)$ & $4(17.4)$ & $7(30.4)$ & $15(65.2)$ \\
Total & 360 & $68(18.9)$ & $41(11.4)$ & $113(31.4)$ & $222(61.7)$ \\
\hline
\end{tabular}

Data reproduced with permission from reference 8

TABLE 2

Frequency of abnormal sphincter of Oddi manometry (SOM) in idiopathic pancreatitis

\begin{tabular}{lccc}
\hline $\begin{array}{l}\text { Author } \\
\text { (reference) }\end{array}$ & $\begin{array}{c}\text { Year of } \\
\text { study }\end{array}$ & $\begin{array}{c}\text { Patients with abnormal } \\
\text { SOM/total number }\end{array}$ & $\begin{array}{c}\text { Frequency } \\
\text { (\%) }\end{array}$ \\
\hline Toouli (11) & 1985 & $14 / 28$ & 58 \\
Catalano (12) & 1993 & $10 / 18$ & 56 \\
Guelrud (13) & 1988 & $17 / 42$ & 40 \\
Sherman (10) & 1992 & $15 / 49$ & 31 \\
Gregg (14) & 1984 & $28 / 125$ & 22 \\
Venu (9) & 1989 & $17 / 116$ & 15 \\
Total & & $101 / 378$ & 27 \\
\hline
\end{tabular}

Several other series have shown that patients with idiopathic pancreatitis have a $27 \%$ to $58 \%$ rate of sphincter of Oddi dysfunction as an apparent explanation for their pancreatitis (9-14) (Table 2). These series only recorded sphincter pressure in one duct (biliary or pancreatic) and often failed to report which duct was studied. When studying both ducts, Fogel et al $(15,16)$ preliminarily reported higher frequencies of basal sphincter abnormality of at least one duct in idiopathic pancreatitis patients (72\%) and chronic pancreatitis patients $(57 \%)$.

The tentative proof that sphincter dysfunction is the cause of pancreatitis in this group is resolution of pancreatitis after sphincterotomy. As listed in Table 3, 80\% of abnormal sphincter patients improved with biliary sphincterotomy. Fortunately for the patient, but unfortunately for pathophysiological clarification, common duct stones, especially tiny ones causing such pancreatitis, are successfully treated by the same means. More recent preliminary evidence shows that such pancreatitis may not respond to biliary sphincterotomy alone when patients with common duct stones have been carefully excluded (Table 4) (17).

\section{FAILED SYMPTOM RELIEF AFTER BILIARY SPHINCTEROTOMY}

The multiple potential causes for failure to respond to biliary sphincterotomy in patients with documented sphincter of Oddi dysfunction are outlined in Table 5. Residual pancreatic sphincter hypertension is one of these causes. Eversman and coworkers (8) found that $90 \%$ of patients with persistent 
TABLE 3

Response to sphincter of Oddi ablation in idiopathic pancreatitis patients with abnormal sphincter of Oddi manometry (SOM)

\begin{tabular}{lcccc}
\hline $\begin{array}{c}\text { Yuthor } \\
\text { (reference) }\end{array}$ & $\begin{array}{c}\text { Year } \\
\text { of } \\
\text { study }\end{array}$ & $\begin{array}{c}\text { Number with } \\
\text { abnormal/ } \\
\text { normal SOM }\end{array}$ & $\begin{array}{c}\text { \% of } \\
\text { patients } \\
\text { improved }\end{array}$ & $\begin{array}{c}\text { Mean follow-up } \\
\text { (months) } \\
\text { abnormal/ } \\
\text { normal SOM }\end{array}$ \\
\hline $\begin{array}{l}\text { Venu (9) } \\
\text { Sherman } \\
\quad 1989)\end{array}$ & 1992 & $16 / 40$ & $94 / 12$ & $36 / 36$ \\
$\begin{array}{c}\text { Catalano } \\
(12)\end{array}$ & 1993 & $10 / 6$ & $73 / 50$ & $15 / 14$ \\
\begin{tabular}{c} 
Total \\
\hline
\end{tabular} & & $37 / 54$ & $80 / 38$ & $-24 /-24$ \\
\hline
\end{tabular}

pain or pancreatitis after biliary sphincterotomy had residual abnormal pancreatic basal sphincter pressure. Johlin (18) had similar findings in a series of 210 patients with abnormal biliary basal pressure. All patients had biliary sphincterotomy. Twenty-six patients failed to improve; they were studied six or more months later and 25 had elevated basal pancreatic sphincter pressure.

\section{TREATING SYMPTOMATIC PATIENTS WITH PANCREATIC SPHINCTER HYPERTENSION}

Pancreatic sphincter hypertension has generally been treated with sphincter ablation. There are no studies evaluating treatment of pancreatic sphincter hypertension with medical therapies that either relax the sphincter or reduce pancreatic juice secretion, which might decrease intraductal hypertension. Patients with recurrent pancreatitis or disabling pain have generally been considered candidates for pancreatic sphincter ablation. The optimal method for sphincter ablation is unknown. Historically, surgical septoplasty or sphincteroplasty was recommended $(19,20)$; however, with increasing experience, endoscopic approaches seem acceptable. The exact depth, type of current and landmarks for such endoscopic sphincterotomy remain uncertain. Two endoscopic techniques may be applied. One method is to place a standard pull-type traction sphincterotome and a cephalad cut up to 5 to $8 \mathrm{~mm}$ through the relatively vascular septum into the pancreatic orifice (whether a stent needs to be placed after traction-type pancreatic sphincterotomy is uncertain but seems appropriate). In the second technique, a pancreatic stent can be placed, and needle-knife sphincterotomy performed over the top of this. These two techniques may be performed with or without prior or simultaneous biliary sphincterotomy. Failure to sever the biliary sphincter may result in transient cholestasis or cholangitis in approximately $5 \%$ of patients.

\section{OTHER REASONS FOR PANCREATIC SPHINCTEROTOMY}

A common reason to cut the pancreatic sphincter, which may not be hypertensive, is to perform therapy within the pancreatic duct. Patients with pancreatic strictures or pancreatic stones usually require ablation of the pancreatic
TABLE 4

Endoscopic treatment in type II pancreatic sphincter dysfunction

\begin{tabular}{lc}
\hline Treatment & $\begin{array}{c}\text { Patients improved/total } \\
\text { number patients (\%) }\end{array}$ \\
\hline Endoscopic sphincterotomy & $5 / 18(28)$ \\
$\begin{array}{l}\text { Endoscopic sphincterotomy + pancreatic } \\
\quad \text { sphincter balloon dilation* }\end{array}$ & $13 / 24(54)$ \\
$\begin{array}{l}\text { Endoscopic sphincterotomy + pancreatic } \\
\quad \text { sphincterotomy** }\end{array}$ & $10 / 13(77)$ \\
Dual endoscopic sphincterotomy & $12 / 14(86)$ \\
\hline
\end{tabular}

${ }^{*} P$ is not significant versus endoscopic sphincterotomy; ${ }^{*} P<0.005$ versus endoscopic sphincterotomy. Data reproduced with permission from reference 17

TABLE 5

Reasons for failure to respond to biliary sphincterotomy performed for suspected or documented sphincter of Oddi dysfunction

Inadequate biliary sphicterotomy

Recurrent biliary stenosis

Residual pancreatic sphincter stenosis

Chronic pancreatitis

Other residual pancreatobiliary disease (ie, stones, strictures, pancreas divisum)

Nonpancreatobiliary cause for pain such as irritable bowel syndrome

sphincter before larger baskets, stents or forceps can be placed up the duct to accomplish the desired therapy. Most of these patients have obvious chronic pancreatitis and appear relatively resistant to serious postprocedure acute pancreatitis. Many such pancreatic sphincterotomies have been reported in patients with pancreatic stones and strictures, but the pancreatic sphincterotomy is often mentioned in passing, without many details. Outcome of therapy is usually more dependent on stricture, stone or pseudocyst resolution than successful sphincterotomy.

\section{EFFICACY OF PANCREATIC SPHINCTER ABLATION}

Results from older surgical series ranged from 50\% to $75 \%$ (good to excellent) pain relief from surgical sphincteroplasty (septoplasty). Nonresponders were often reported to have chronic pancreatitis or narcotic addiction. Most older series did not use current manometric techniques (preoperatively or intraoperatively) for patient evaluation or selection.

Guelrud et al (17) reported the frequency of pancreatitis attack relief (Table 4). Combined endoscopic pancreatobiliary sphincterotomy resolved pancreatitis in 22 of 27 patients. Performing both sphincterotomies at the initial endoscopic session was more effective and without increased complications; success was reported in 12 of 14 patients $(86 \%)$ undergoing both sphincterotomies versus in 10 of 13 patients $(77 \%)$ undergoing either endoscopic or pancreatic sphincterotomy. 
TABLE 6

Ability of surgical sphincteroplasty versus endoscopic sphincteroplasty to lower basal sphincter pressure

Elevated basal sphincter pressure

\begin{tabular}{lccccc}
\hline $\begin{array}{l}\text { Prior } \\
\text { therapy }\end{array}$ & $\begin{array}{c}\text { Total } \\
\text { number of } \\
\text { patients }\end{array}$ & $\begin{array}{c}\text { Pancreas: } \\
\mathbf{n}(\%)\end{array}$ & $\begin{array}{c}\text { Biliary: } \\
\mathbf{n ~ ( \% )}\end{array}$ & $\begin{array}{c}\text { Both: } \\
\mathbf{n}(\%)\end{array}$ & $\begin{array}{c}\text { Neither: } \\
\mathbf{n}(\%)\end{array}$ \\
\hline Surgical & 27 & $1(3.7)$ & $0(0)$ & $0(0)$ & $26(96.3)^{*}$ \\
Endoscopic & 62 & $16(25.8)$ & $0(0)$ & $4(6.5)$ & $42(67.7)^{*}$ \\
\hline
\end{tabular}

$* P=0.004$

TABLE 7

Complication frequency using pancreatic sphincterotomy

\begin{tabular}{|c|c|c|c|c|c|}
\hline $\begin{array}{l}\text { Author } \\
\text { (reference) }\end{array}$ & $\begin{array}{l}\text { Year } \\
\text { of } \\
\text { study }\end{array}$ & $\mathbf{n}$ & $\begin{array}{l}\text { Number of } \\
\text { patients } \\
\text { with } \\
\text { pancreatitis }\end{array}$ & $\begin{array}{c}\text { Number of } \\
\text { patients with } \\
\text { no other } \\
\text { complications }\end{array}$ & $\begin{array}{l}\text { Total } \\
\text { compli- } \\
\text { cations }\end{array}$ \\
\hline $\begin{array}{c}\text { Kozarek } \\
(23)\end{array}$ & 1994 & 56 & $4(7.1 \%)$ & $2(3.6 \%)$ & $6(10.7 \%)$ \\
\hline $\begin{array}{r}\text { Parsons } \\
(24)\end{array}$ & 1995 & 31 & $1(3.2 \%)$ & $0(0.0 \%)$ & $1(3.2 \%)$ \\
\hline Esber (25) & 1996 & 236 & 33 (14.0\%) & $4(1.7 \%)$ & 37 (15.7\%) \\
\hline Total & & 323 & 38 (11.8\%) & 6 (1.9\%) & $44(13.6 \%)$ \\
\hline
\end{tabular}

The mortality rate was $0 \%$ in all three studies

Johlin (18) reported secondary therapeutic outcome in 25 persistently symptomatic patients with residual manometrically documented pancreatic basal sphincter hypertension after biliary sphincterotomy. After endoscopic pancreatic sphincterotomy (or surgical sphincteroplasty in a few patients), 16 of 25 reported at least $80 \%$ pain relief.

Okolo et al (21) preliminarily reported the frequency of pain relief after endoscopic pancreatic sphincterotomy $(12 \%$ had surgical sphincteroplasty); $60 \%$ of chronic pancreatitis and sphincter dysfunction patients had at least $50 \%$ pain relief after a mean follow-up of 16 months.

Manometric documentation of successful pancreatitis sphincter ablation has not been assessed in patients achieving symptom resolution. While of scientific interest, this documentation would require manometry on asymptomatic patients. The present authors performed manometry on 89 patients with persistent or recurrent pain or pancreatitis after surgical or endoscopic sphincterotomy (22). Table 6 shows that surgical sphincteroplasty was more effective than endoscopic sphincteroplasty in lowering basal sphincter pressure into the normal range. This series does not address the frequency of pain relief in these two therapies.

\section{COMPLICATIONS OF PANCREATIC SPHINCTEROTOMY}

Complication frequency has been reported from three series using pancreatic sphincterotomy (Table 7) (23-25). As with biliary sphincterotomy, pancreatic sphincterotomy complication rates are highest when sphincterotomy is done for recurrent pancreatitis or just sphincter dysfunction associated with pain, and are lower when done for chronic pancreatitis such as pancreatic stone disease.

Tarnasky et al (26) reported that pancreatic sphincter hypertension is a risk factor of post-ERCP pancreatitis. This group also preliminarily reported that stenting the pancreatic sphincter in such patients (after biliary sphincterotomy) significantly decreased the postprocedure pancreatitis rate from $25 \%$ to $2 \%$ (27). The present authors similarly found that if biliary sphincterotomy alone was done in suspected or documented sphincter of Oddi dysfunction patients, the postsphincterotomy pancreatitis rate was very high (20\% to $25 \%)$. However, if a pancreatic stent was placed and a combined pancreatobiliary sphincterotomy was performed, the pancreatitis rate dropped by nearly half. These studies show that manipulating the pancreatic sphincter - but not opening it - has an unacceptably high complication rate.

\section{CLINICAL DECISION PROCESS}

When faced with sphincter of Oddi dysfunction patients with abnormal biliary and pancreatic basal pressure, the clinician must decide whether to cut the biliary and/or pancreatic sphincters. The time-honoured approach is to just sever the biliary sphincter. There is increasing evidence that stenting the pancreas increases sphincterotomy safety. Data from Guelrud (17) indicated that cutting both sphincters at the initial session is most efficacious (Table 4). Randomized studies are in progress to address the safety of this approach.

\section{SUMMARY}

Pancreatic sphincter hypertension is a variant of biliary sphincter hypertension, which is one of the core common causes of residual pain after biliary sphincterotomy in type II or III patients. Such patients need careful evaluation for chronic pancreatitis, residual pancreatic sphincter hypertension and duodenal motor disorders as a cause of their upper abdominal pain. There are some long term outcome data from surgical series indicating that approximately one-half to three-quarters of these patients have continued pain relief over five to 10 years; however, further long term outcome data are not yet available from endoscopic series. Such pancreatic sphincter therapy is evolving and until more data on optimal techniques are available, its use should be restricted to large centres where accumulated data can assist in the development of the state of the art.

\section{REFERENCES}

1. Sherman S, Hawes RH, Troiano FP, Lehman GA. Pancreatitis following bile duct sphincter of Oddi manometry: utility of the aspirating catheter. Gastrointest Endosc 1992;38:347-50.

2. Sherman S, Hawes RH, Madura JA, Lehman GA. Comparison of intraoperative and endoscopic manometry of the sphincter of Oddi. Surg Gynecol Obstet 1992;175:410-8.

3. Guelrud M, Mendoza S, Rossiter G, Villegas MI. Sphincter of Oddi manometry in healthy volunteers. Dig Dis Sci 1990;35:38-46.

4. Raddawi HM, Geenen JE, Hogan WJ, Dodds WJ, Venu RP, Johnson GA. Pressure measurements from biliary and pancreatic segments of the sphincter of Oddi. Comparison between patients with functional abdominal pain, biliary or pancreatic disease. Dig Dis Sci 1991;36:71-4. 
5. Rolny P, Arleback A, Funch-Jensen P, Kruse A, Jarnevot G. Clinical significance of manometric assessment of both pancreatic duct and bile duct sphincter in the same patient. Scand J Gastroenterol 1989;24:751-4.

6. Vestergaard H, Kruse A, Rokkjaer M, Frobert O, Thommesen P, Funch-Jensen P. Endoscopic manometry of the sphincter of Oddi and the pancreatic and biliary ducts in patients with chronic pancreatitis. Scand J Gastroenterol 1994;29:188-92.

7. Silverman WB, Ruffolo TA, Sherman S, Hawes RH, Lehman GA. Correlation of basal sphincter pressure measured from the bile duct and pancreatic duct in patients with suspected sphincter of Oddi dysfunction (SOD). Gastrointest Endosc 1992;38:440-3.

8. Eversman D, Sherman S, Bucksot L, et al. Frequency of abnormal biliary and pancreatic basal sphincter pressure at sphincter of Oddi manometry (SOM) in 593 patients. Gastrointest Endosc 1997;45:131A

9. Venu RP, Geenen JE, Hogan W, Stone J, Johnson GK, Soergel K. Idiopathic recurrent pancreatitis: an approach to diagnosis and treatment. Dig Dis Sci 1989;34:56-60.

10. Sherman S. Idiopathic acute recurrent pancreatitis (IRP): endoscopic approach to diagnosis and therapy. Gastrointest Endosc 1992;38:261A.

11. Toouli J, Roberts-Thomson IC, Dent J, Lee J. Sphincter of Oddi motility disorders in patients with idiopathic recurrent pancreatitis. Br J Surg 1985;72:859-63.

12. Catalano MF, Sivak MV, Falk GW, et al. Idiopathic pancreatitis (IP): Diagnostic role of sphincter of Oddi manometry (SOM) and response to endoscopic sphincterotomy (ES). Gastrointest Endosc 1993;39:310A.

13. Guelrud M. Papillary stenosis. Endoscopy 1988;20:193-202.

14. Gregg JA, Carr-Locke DL. Endoscopic pancreatic and biliary manometry in pancreatic, biliary, and papillary disease, and after endoscopic sphincterotomy and surgical sphincteroplasty. Gut 1984;25:1247-54.

15. Fogel E, Eversman D, Sherman S, Lehman GA. Utility of sphincter of Oddi manometry (SOM) in chronic pancreatitis (CP). Gastrointest Endosc 1997;45:132A.
16. Fogel E, Eversman D, Yu A, Sherman S, Lehman GA. Frequency of sphincter of Oddi dysfunction in idiopathic pancreatitis. Gastrointest Endosc 1997;45:132A.

17. Guelrud M, Plaz J, Mendoza S, Beker B, Rojas O, Rossiter G. Endoscopic treatment in type II pancreatic sphincter dysfunction. Gastrointest Endosc 1995;41:398A.

18. Johlin FC. Intestinal dysmotility in patients with sphincter of Oddi dysfunction. A reason for failed response to sphincterotomy. Dig Dis Sci 1994;39:1942-6.

19. Madura J. Nardi test and biliary manometry in the diagnosis of pancreatobiliary sphincter dysfunction. Surgery 1981;90:588-95.

20. Anderson TM, Pitt HA, Longmire WP. Experience with sphincteroplasty and sphincterotomy in pancreatobiliary surgery. Ann Surg 1995;201:399-406.

21. Okolo P III, Pasricha PJ, Kalloo AN. Efficacy of endoscopic pancreatic sphincterotomy: A long-term follow up study. Gastrointest Endosc 1997;45:163A.

22. Sherman S, Madura J, Fogel E, Eversman D, Bucksot L, Baute P, Flueckiger J. Pancreatic sphincter basal pressure after endoscopic and surgical pancreatic sphincter ablation. Gastrointest Endosc 1997;45:148A.

23. Kozarek RA, Ball TJ, Patterson DJ, Brandabur JJ, Traverso W, Raltz S. Endoscopic pancreatic duct sphincterotomy: indications, technique, and analysis of results. Gastrointest Endosc 1994;40:592-8.

24. Parsons WG, Howell DA, Qasseem T, Hanson BL. Pancreatic duct sphincterotomy without stenting. Gastrointest Endosc 1995;41:427A.

25. Esber E, Sherman S, Earle D, Pezzi J, Gottlieb K, Lehman G. Complications of major papilla endoscopic sphincterotomy: A review of 236 patients. Gastrointest Endosc 1996;43:459A.

26. Tarnasky P, Cunningham J, Cotton $\mathrm{P}$, et al. Pancreatic sphincter hypertension increases the risk of post-ERCP pancreatitis. Endoscopy 1997;29:252-7.

27. Tarnasky PR, Palesch Y, Cunningham JT, Cotton PB, Hawes RH. Pancreatic stenting prevents pancreatitis after biliary sphincterotomy in patients with sphincter of Oddi Dysfunction: A prospective randomized trial. Gastrointest Endosc 1997;45:150A. 


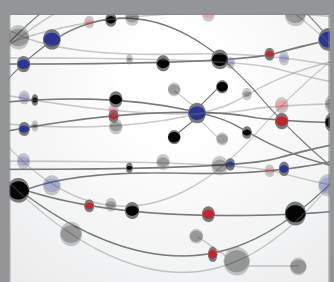

The Scientific World Journal
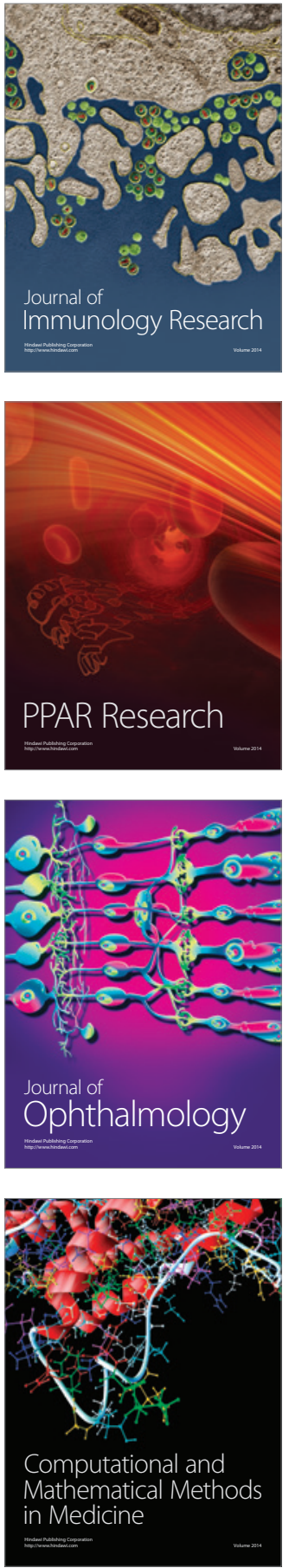

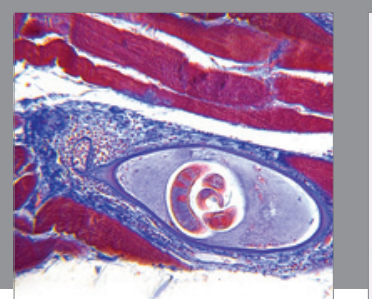

Gastroenterology Research and Practice

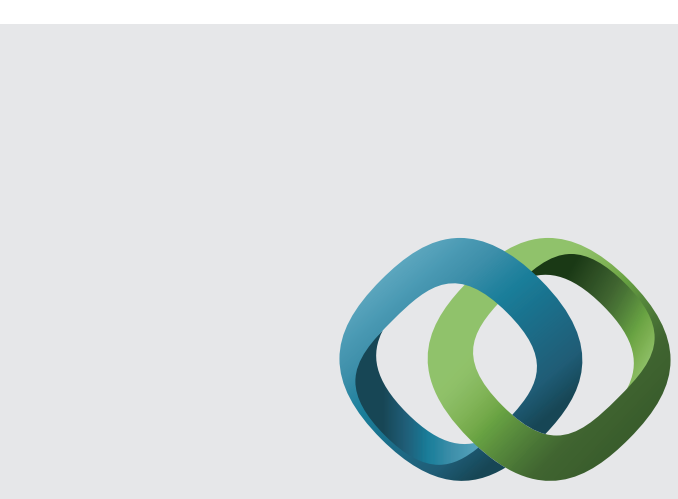

\section{Hindawi}

Submit your manuscripts at

http://www.hindawi.com
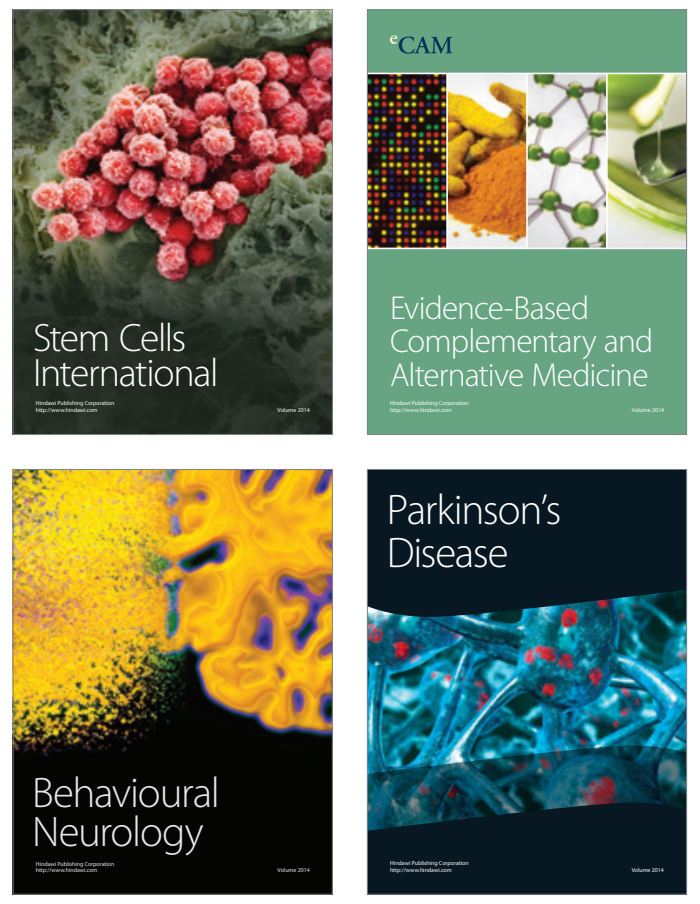
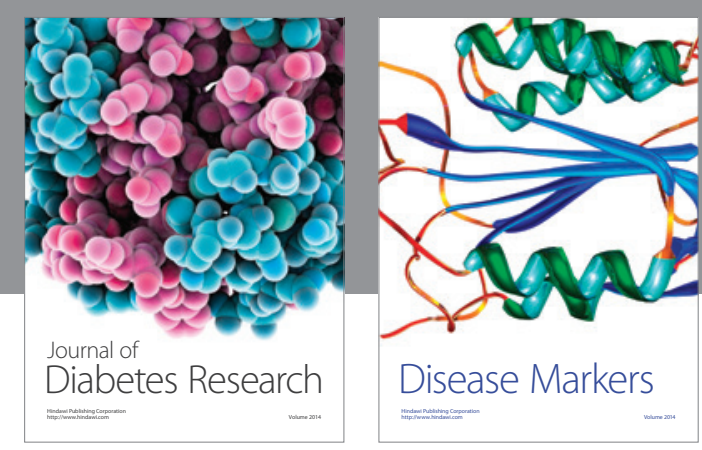

Disease Markers
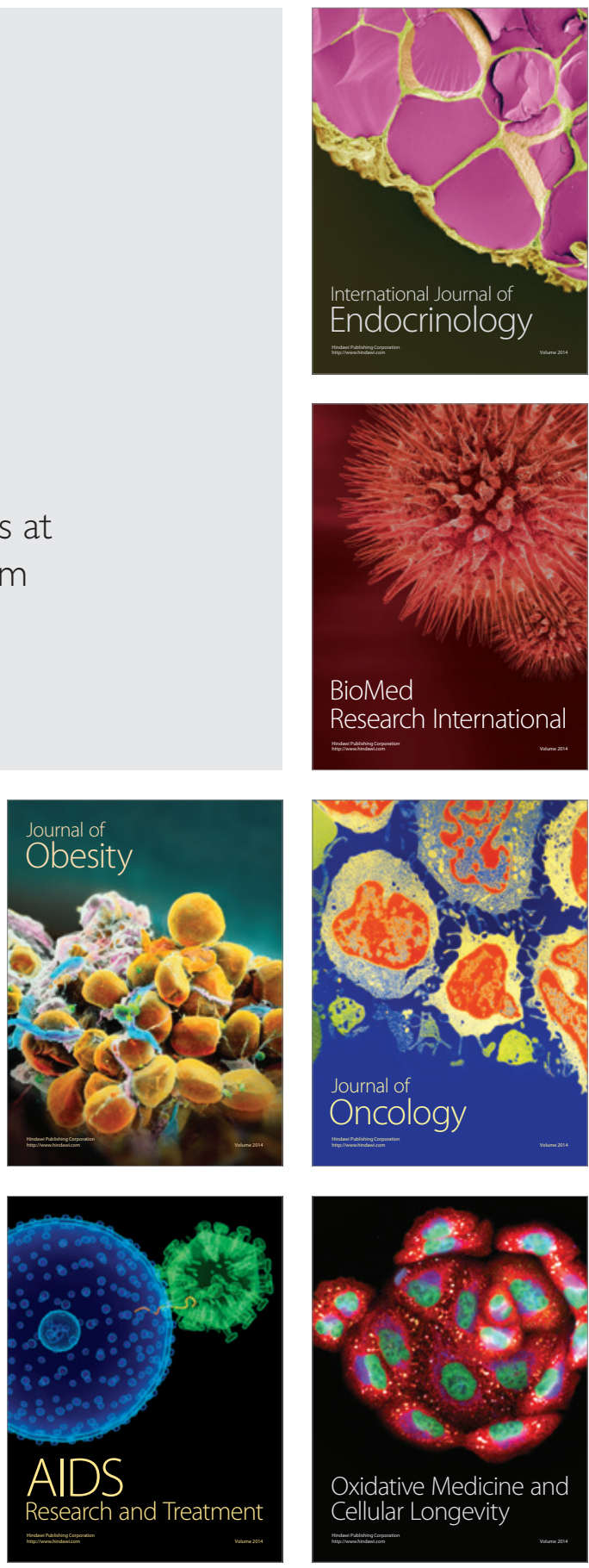